\title{
Commercial Considerations on the Presentation of Results in Accordance with the Proposal for a Community Directive on the Accounts of Insurance Undertakings
}

\author{
by Hans Joachim Welzel*
}

\section{Introduction}

In January 1987 the European Commission submitted to the Council of Ministers a proposal for a Directive which has been published in revised form in the Official Journal of the European Communities as "Proposal for a Council Directive on the annual accounts and consolidated accounts of insurance undertakings" dated 8 April 1987.1)

The proposed Directive contains amendments and additions specifically for the insurance industry to the Fourth Company Law Directive (the "accounts" directive) dated 25 July 1978 and to the Seventh Company Law Directive on consolidated accounts dated 13 June 1983. These include special classification rules for the layout of the balance sheet and profit and loss account (P\&L). Whilst the balance sheet layout does not entail any significant differences from the German format - Schedule I to the "Änderungsverordnung" (amending order) dated 23.12.19862) - the presentation of profit and loss does contain a number of systematic differences. These will be highlighted below and critically examined against the background of the German regulations currently in force.

\section{Apportionment and content of the underwriting ("technical") accounts}

In the same way as the new German requirements of form mentioned above, which become compulsory for the first time for financial years starting after December 31, 1986, the proposed Directive also provides for two different versions of the underwriting ("technical")

*Vice Secretary General of the Geneva Association, Cologne.

1) Official Journal of the European Communities no. C 131 dated 18 May 1987, p. 1.

2) Third Order amending the Order governing the accounts of insurance companies dated 23 December 1986, Federal Law Gazette 1987 I, p. 2. 
account, namely for life insurance business on the one hand and for so-called "non-life" insurance business (i. e. property and casualty insurance) and reinsurance business ${ }^{3)}$ on the other, both of which are coupled with a "non-technical" account in a single format.

The differences between the two technical accounts in the proposed Directive are less pronounced, however, than in our own system. Common to both systems is the difference in the treatment of investment income and expenses: investment income and expenses for life insurance business are shown initially in the technical part of the profit and loss account whilst for non-life and reinsurance business, in contrast, they are shown in the non-technical part. "Interest" can be transferred between the technical and non-technical parts of the account by using the heading "allocated investment return". The proposed Directive leaves the amount of this transfer of investment return to be decided by the individual insurance company.

Our P \& L schedules only allow non-life and reinsurance companies to transfer income in this way; the accounting regulations ("VUBR") published by the supervisory authority for the insurance industry restrict the amount of investment return transferred to the technical account for all practical purposes to computed interest on interest-bearing underwriting liabilities, in order to prevent any (fictitious) underwriting losses occurring as a result of discounting when they are settled.

By extending the transfer option to life insurance business (in the reverse direction) and giving the option to companies, the proposed Directive leaves open the substantive question of the inclusion of investment return in the technical profit and loss account generally - i. e. for all classes of business - and leaves the decision to individual companies.

In view of the importance of this type of income, leaving such an option to insurance undertakings is not likely to be exactly beneficial for inter-company comparisons of underwriting results; compared with rules on content already in existence in individual countries within the EC, allowing companies an option is positively counterproductive as regards harmonisation. Compared with the existing German system the proposed Directive imposes or allows even more variations in content, most notably for example through the absence of any allocation of translation differences on foreign currency items, the system of recording income and expenses from the provision of services - not relating to the provision of insurance - for other companies in the insurance sector (e.g. insurance broking or managing co-insurance), and the systematic widening of the principle of functional divisions for the allocation of operating costs (which will be examined in more details later).

The last of the above variations would have a detrimental effect on the technical account; the substantive effects of the changes under the other two headings cannot be predicted with any certainty; inclusion of the income and expenses on services mentioned above would tend to benefit the technical account.

3) Health insurance (including the type operated like life insurance) is included in non-life business by the proposed Directive. 


\section{Distinction between direct and indirect insurance business}

Under Article 28 of the proposed Directive, separate technical accounts in accordance with Article 29 are required for the life and non-life classes of insurance business, no distinction being made between direct and indirect business for the purposes of these accounts. On this basis a separate account for either of the latter two types of business would arise if only one type was operated or both classes of insurance (life and non-life) were operated only for direct or indirect business. "Pure" cases for accounting purposes would therefore arise only if direct and indirect insurance business were not conducted together in the same class of insurance.

The treatment required by the proposed Directive is apparently aimed at isurance companies which (owing to the lack of specialization) are allowed to carry on direct insurance business in both classes of insurance, because only the classes of insurance are separated for profit and loss account purposes, no distinction being made between direct and indirect business within either class of business - something which in various quarters is also regarded as commercially desirable because of the differences in structure and risks involved.4)

The fact that, under the system proposed in the Directive on insurance company accounts (with separate accounts for each class of business), direct and indirect insurance have to be shown together within each class of business - in other words share the same classification fate - may pose problems for indirect life insurance business. On this basis, for example, a German composite insurer subject to specialization carrying on direct (and possibly indirect) non-life business as well as life reinsurance business would have to prepare two separate technical accounts: one of the "non-life insurance business" type for its direct (and possibly indirect) property and casualty business and one of the "life insurance business" type for its life reinsurance business. A reinsurer engaged in both classes of business would have to do the same.

Now, however, as explained at the outset, the prescribed layout for the "life" technical account requires the original income and expenses on investments to be included. Where these are retained by the ceding insurer, the amount to be shown is limited to the interest received on deposits. Otherwise in the cases indicated above it would only be possible to make the clear allocation required for such treatment if the investments relating to life reinsurance business were kept separate. In constrast to non-specialized insurance companies in other European Community countries, however, we do not have the legal background for this.

One way of resolving this problem would be to show life reinsurance business in such cases in the same way as non-life insurance business, as envisaged under our own accounting regulations currently in force. No special ruling would then be required for reinsurance

\footnotetext{
4) cf. Laass, Wolfgang: The layout of annual financial statements for insurance companies in the European Community under the special Draft Directive for insurance undertakings dated 20 June, 1979, in the magazine Wirtschaftsprüfung, Vol. 34 (1981, p. 412;
}

Lorch, Manfred: The accounting regulations for insurance companies oriented towards disclosure, Karlsruhe 1974, p. 108 et seq. 
business assumed by life insurance companies; direct and indirect business in such cases would be shown together. On the basis that the "fate-sharing" concept mentioned above does not require separate accounts for direct and indirect business if a uniform layout is used, the situation could arise under the solution suggested above that the total reinsurance business - i. e. including "life" - assumed by a composite insurer in a Member State subject to specialization would be shown together with direct insurance business in a combined technical profit and loss account, whereas a non-specialized insurer who in addition to direct and indirect life insurance business, also - and only - underwrites indirect non-life business would have to show the latter separately.

\section{The "gross" principle - treatment of reinsurance ceded}

Of particular interest to insurance companies in connection with the presentation principle embodied in the rule prohibiting set-offs - which, on the basis of Article 7 of the Fourth EC Directive in conjunction with Article 1 of the proposed Directive, also applies to insurance undertakings - is the question whether and to what extent the components of reinsurance business ceded are to be shown separately or set off against the corresponding gross figures.

For life and health insurance companies our own accounting regulations currently in force stipulate a strict gross treatment and for non-life and reinsurance companies, in contrast, a qualified gross treatment under which - by reference to the overall account - the expense of claims incurred only has to be shown net.

From this point of view the Brussels proposal embodies a modified gross system under which reinsurance premiums ceded, the reinsurers' proportion of claim payments (non-life insurance) and reinsurance commissions and profit participations (combined, where appropriate, with other commissions received) are shown separately as a deduction from the corresponding gross amounts.

From the point of view of the amount of information provided, this treatment puts the Directive proposed by Brussels somewhere in between the German variations of presentation outlined above. With set-offs shown separately and the sort of distinctions made, it is something of a compromise - no doubt having due regard for the legally and commercially disputed nature of the full gross treatment as outlined at the beginning, a situation which is also reflected in the different regulations governing disclosure in the various Member States of the European Community.

Without going into the "theoretical argument" s) in more detail, there is one commercial consideration to be noted: the treatment proposed by the European Commission satisfies neither the requirements of the "source of earnings" theory (because it does not disclose all the earnings-related figures resulting from reinsurance ceded and therefore does

5) $\mathrm{cf}$. in this connection Hesberg, Dieter: The treatment of reinsurance ceded in the financial statements of non-life insurance companies, in: Wirtschaftsprüfung, Vol. 32 (1979), pp. 361-375;

Oos, Johannes: The treatment of reinsurance ceded in the financial statements of non-life insurance companies, in: Wirtschaftsprüfung, Vol. 32 (1979), pp. 604-613. 
not reveal the "reinsurance result") nor the "production factor" theory which requires the "reinsurance" production cost - the difference between reinsurance premium and reinsurance commission - to be shown ${ }^{6}$ ) (because the wording of the Directive under the relevant deduction heading in the prescribed layout seems to include not just reinsurance commissions but also commissions on services rendered to other companies).

\section{The functional analysis of costs}

The combination of reinsurance commissions and profit participations with commission income from services entails differences from our own profit and loss account system which go beyond the treatment of reinsurance business. Whereas in the German system income and expenses on such services are recorded separately from the revenue components of the insurance business (direct and indirect) in the general part of the P \& $\mathrm{L}$ within the framework of a system of classifying expenses which is based - albeit not without exceptions - on operational (functional) considerations, the proposed Directive neither requires any such apportionment of results nor eliminates the earnings on such business from the technical account.

It is possible that more attention has been paid in this connection to non-specialized companies, where such sources of earnings may play a relatively minor role. In our country the (re-)inclusion of such earnings in the technical profit and loss account could have an adverse effect on the informative value of the technical account in view of the generally practised separation of functions unless the result was at least analysed appropriately in the Notes.

All in all, the analysis of operating costs in the proposed Directive does not seem to differentiate as effectively as our own regulations currently in force under which a distinction can be made mainly between the functional divisions of new business (life and health insurance only), (claims) settlement, insurance operations (comprising several functions), investment management, services and "company as a whole". The only functional areas which are mentioned are (claims) settlement (Art. 33) and investment management (Art. 29). In addition to this the prescribed layout for the $P \& L$ makes a distinction between "commissions" and "administrative expenses".

Even if this does not produce the same sort of loopholes in the system as those which arise in our system from the exclusion of depreciation on office equipment, pension costs and operating taxes from the functional classification, the breakdown still does not correspond to the layout proposed in the Fourth Company Law Directive. The latter allows a choice for the classification of expenses only between a functional analysis in the P\&L (under the cost of sales system) or a classification by type (when the total or gross cost method is used). A mixture of the two, as envisaged in the proposed Directive by showing a type of expense (new business commissions) within the framework of a functionally-based analysis, is not justified by the peculiarities of the insurance industry.

6) cf. Farny, Dieter: The "price" of reinsurance in theory and practice, in: ZfV, Vol. 14 (1963), pp. 737-740. 
As the commissions to be shown separately, according to the explanatory notes on the heading given in Art. 35 ("fees paid... for services rendered in respect of business introduced to the insurance undertaking"), are to be regarded as commissions for the acquisition of new business and accordingly relate only to one functional division, disclosure of this cost category is not incompatible with the functional analysis required; but the disclosure of functional expenses limited to only one particular type of expense and (according to the explanatory notes) probably only to "direct insurance business" does not conform with the system.

The explanatory memorandum to the Directive contains the following comment on this treatment: With regard to the methods of selling through an "employed sales force" or "independent selling agents", analysts of insurance company accounts are often interested in "comparing the results of the different methods of operation and it seems desirable that the extent to which an insurance undertaking pays commissions to outside parties should be revealed".

In this connection it must be said that such a comparison would only be possible at all within the framework of a purely functional analysis. Even a partial business comparison is not possible with the disclosure of (new business) commissions envisaged because the comparable figure through the alternative marketing channel is not disclosed.

In the case of reinsurance business assumed, the explanatory notes on the two expense headings mentioned above indicate that reinsurance commissions paid would have to be shown together with the reporting company's own administrative expenses; because reinsurance commission, by nature, is not comparable with commissions on new business paid by the direct insurer.

All things considered, the method of disclosing operating costs chosen in the proposed Directive appears to be relatively weakly functionally-based from the commercial point of view and not systematically defined. Under Article 36, for example, only staff costs are allocated to the functional divisions "claims settlement" and "investment management" referred to there; the relevant non-personnel expenses evidently have to be recorded - in contravention of the system - under the heading "administrative expenses".

From the commercial point of view a consistent, functionally-based classification system corresponding to the cost of sales method in the Fourth Company Law EC Directive would be desirable - albeit in a form specifically adapted for the insurance industry. As far as a definition of the functional divisions is concerned, the German regulations currently in force provide, in my view, a workable model.

\section{The revenue apportiomment of underwriting receipts and payments}

The profit and loss account treatment of amounts received and paid (premiums, policyholders' benefits, operating costs) corresponding to "technical provisions" (underwriting funds and provisions) is typically based on two methods under which the receipts and payments are taken without apportionment to the profit and loss account: (literally) the "turnover" inethod and "balanced turnover" method. Under the first method revenue apportionment is effected by taking the opening and closing balances of the provisions at the beginning and end of the year and under the second method by taking only the net change in the provisions to the profit and loss account. 
These contrast with the earnings method on which the standard layout in the EC accounts directive and in $\S 275$ of the German Commercial Code is based, under which only figures affecting net earnings are taken as income and expenses to the profit and loss account.

The international treatment of receipts and payments corresponding to technical provisions is based exclusively on the turnover method or - in the vast majority of cases, I believe - on the balanced turnover method, the German system also having been switched to the latter from the turnover method as part of the accounting reform package in 1973.

A common feature of both these methods of presentation which dictate insurance practice is that they deliberately do not show income from the run-off of provisions separately but set it off against the relevant expense heading. This is also why the treatment of claims incurred at item 5 on $\mathrm{P} \& \mathrm{~L}$ schedule III under the current regulation governing published accounts only pays lip service to the earnings method, given that only payments and the change in the provision (components of the balanced turnover method) are combined taking into account the run-off result of claims incurred, practically as an additional or negative expense component.

The proposal for a Community Directive on the accounts of insurance undertakings is based on the "balanced turnover" method - with a minor difference between "life" and "non-life" insurance business in the analysis of the heading "claims incurred" which is of no importance for the distinction between the methods of presentation being made here. Apart from the uniformity of method, this treatment has the advantage of clarity and conciseness in the presentation of claims incurred as the most important expense component in the technical account. A further improvement could be achieved by combining, as in our system, claims paid in the current year with the change in the claims reserve (relating to the same type of expense) to arrive at the claims expense actually chargeable to the accounting period under review.

The advantage claimed by writers for the balanced turnover method over the earnings method - that the separate disclosure of payments and change in the provision indicated above provides more meaningful financial information ${ }^{7)}$ - would not be lost by combining the two, because the claims reserve has to be shown separately in the balance sheet and the amount of the change can be calculated by comparing the balances at the beginning and end of the year.

In order to be able to calculate the actual claims expense in the same way when using the earnings method, the income and expenses from the run-off of the previous year's claims reserves would have to be shown separately in addition to the expense of current year claims - gross and net in order to comply with the gross method adopted in the proposed Directive. Furthermore, under this method of disclosing earnings, the inclusion - substantively correct - of the actuarially calculated annuity reserve means that a proportion of notional interest income would have to be included in the run-off result or shown separately in an appropriate manner, complicating the account even more.

\footnotetext{
7) cf. Lorch, Manfred: as above, p. 57.
} 
Limiting separate disclosure to the current year claims expense, as apparently envisaged under the system proposed in the Fourth Directive, would however give an inadequate picture of the earnings situation of an insurance company; ${ }^{8)}$ because neither the actual claims expense nor the influence of reinsurance on the total gross claims expense (which is apparently intended to be disclosed under the gross system) would be identifiable. In furtherance of the "condensed" treatment of claims expenses promoted by the balanced turnover method there is another departure in principle from the revenue accounting system embodied in the earnings method and prohibition against set-off, namely setting off the claims expense against income from subrogation rights and salvage.

As compensation for the fact that the current year claims expense and the run-off result on the previous year's provisions are not disclosed separately, $\S 13(2)$, sentence 8 , of our current regulation governing the published accounts of non-life insurance companies requires the current year loss ratios (gross and net) for the various classes of direct insurance business which have to be shown separately to be disclosed in the Notes. By comparing the net current year ratios with the actual loss ratio net of reinsurance (which can be ascertained from the profit and loss account), the relevant run-off result can be calculated - with certain reservations - both in relation to net earned premiums and in absolute terms. In this way a commercially significant partial result, ${ }^{9)}$ albeit of doubtful validity, can be obtained under our system. No comparable information is expressly envisaged in the proposed Brussels Directive. The question is whether Art. 29 (2) of the Fourth EC Directive - which according to Article 1 of the proposed Directive on the accounts of insurance undertakings is also to apply to insurance companies - requires run-off results to be disclosed. This regulation states that the amount and nature of income and expense items relating to a different financial year have to be explained in the Notes unless they are immaterial for an assessment of the results.

This requirement is probably based on revenue apportionment considerations associated with Schmalenbach's well-known "dynamic" approach to annual accounting which requires revenue factors not relating to the period under review to be eliminated in the interests of arriving at a comparable result for the period.

Even if, strictly speaking, the run-off results of provisions have to be regarded as earnings components relating to a different period (as most academic writers maintain ${ }^{10)}$ ), the

8) cf. also in this connection Kohlstruck, Joachim-Friedrich: The draft Directive for harmonising the accounting regulations for insurance undertakings, in Wirtschaftsprüfung, Vol. 32 (1979), p. 550.

9) cf. Perlet, Helmut: Provisions for claims outstanding in commercial and tax balance sheets, Karlsruhe 1986, p. 109 et seq;

Welzel, Hans Joachim: Basic questions on the reform of the published accounts of insurance companies, in VW, Vol. 28 (1973), p. 430.

10) cf. Farny, Dieter: Book-keeping and periodic accounting for insurance companies, 2nd edition Wiesbaden 1985, p. 104; Lorch, Manfred: as above, p. 116; p. 734

Angerer, August; The accounts of insurance companies - ideal and reality, in ZfV, Vol. 23 (1972), 
comparability of results between accounting periods is not normally affected thanks to the relatively stable permanent rotation of provisions - itself due to the conservative approach which is mandatory in calculating provisions and to a certain amount of collective balancing - so that the above-mentioned reporting requirement in the Notes probably does not apply to the run-off results of technical provisions.

This view was apparently shared by those responsible for drafting the German legislation, because $\$ 55(4)$ of the Insurance Supervision Law (VAG) makes clear that the explanatory provision contained in Art. 29(2) of the Fourth Directive, incorporated into German law by $\$ 277$ (4) of the German Commercial Code (HGB), does not apply to insurance companies.

Owing to the differences in subject-matter dealt with by the two regulations, it is doubtful whether the special provision contained in Art. 33 (2) of the proposed Directive on the accounts of insurance undertakings relating to adjustments to certain provisions is an indication that the reporting requirement concerning transactions relating to a different accounting period does not apply to the technical run-off results.

Art. 33(2) states:

"Where the amount of adjustments of claims in respect of previous years still outstanding at the balance sheet date is material, it shall be disclosed in the notes on the accounts."

This explanatory provision in relation to the claims reserve is unclear in many respects, even with the help of the relevant part of the explanatory memorandum which states that this provision takes into account the fact that "it is occasionally discovered that provisions for claims outstanding need to be revised sharply upwards, sometimes many years after the provision (perhaps relating to claims incurred but not reported) was first created". In this connection reference is made to developments in liability insurance in the United States with regard to asbestosis cases.

Adjustments to previous year provisions are part of the periodic revaluation of provisions for claims outstanding (claims reserves) and are of necessity becoming more material in view of the considerable importance of this item in insurance company balance sheets. The purpose of the regulation and the example given in the explanatory memorandum seem to indicate that the reporting requirement relates only to exceptional adjustments involving material increases. The crucial point is the reference factor to which this relates: class of insurance, category or sub-category, or even individual claims? If the amount referred to in the explanation relates to a class of insurance or to insurance categories, is it the net balance between individual upward and downward adjustments? What is the criterion for deciding what is "material"? In this connection the explanatory memorandum talks about having an "important effect upon the total results".

Doubts also arise about the informative value of this information, which relates only to one factor in the run-off result, the importance of which may even be less than the total of other "normal" adjustments. For this reason also, therefore, this information cannot in my opinion be regarded as being instead of the reporting obligation concerning earnings components relating to a different accounting period required by Art. 29(2) of the Fourth Directive. 


\section{Reporting by lines of business}

Probably the most conspicuous difference between the proposed Directive and the German system of accounting for profits and losses is the absence of technical underwriting accounts for separate lines of business in non-life and reinsurance companies.

Instead of the breakdown of sales between geographical markets and categories of activities required by Art. 43(1) 8 of the Fourth Directive, Art. 58(1) of the proposed Directive requires gross premiums from non-life insurance business to be analysed - separately for direct and indirect business - between certain categories of insurance which account for more than $10 \%$ of the gross premium income in either of those two sectors.

For life insurance companies the same applies to recurring premiums, single premiums, group insurance premiums and investment-linked insurance premiums. No further information on individual lines of business is required.

It must be doubted whether such limited disclosure of information on separate lines of business does justice to the special nature of the insurance business given that certain profit and loss information which is crucial for a proper evaluation of company results cannot be identified. ${ }^{11)}$ Compared with the German grid-like system of differentiation - vertically by source of earnings and horizontally by line of business - the breakdown of results proposed in the Directive looks positively sparse and commercially unsatisfactory on questions of principle.

${ }^{11)} \mathrm{cf}$. in this connection Richter, Horst: Informative value of line accounting, in: WÜBA-Gazette - anniversary edition to celebrate 150 years of the Württembergische und Badische VersicherungsAktiengesellschaft, Heilbronn 1987, pp. 12-14. 


\section{BIBLIOGRAPHY}

ANGERER, August: Die Rechnungslegung der Versicherungsunternehmen - Wunsch und Wirklichkeit, in: ZfV, 23. Jg. (1972), S. 734-740.

FARNY, Dieter: Buchführung und Periodenrechnung im Versicherungsunternehmen. 2. Aufl. Wiesbaden 1985.

FARNY, Dieter: Der "Preis" für Rückversicherung in Theorie und Praxis, in: ZfV, 14. Jg. (1963), S. 737-740.

HESBERG, Dieter: Zum Ausweis des passiven Rückversicherungsgeschäftes im Jahresabschluß der Schaden- und Unfallversicherungsunternehmen, in: WPg, 32. Jg. (1979), S. 361-375.

KOHLSTRUCK, Joachim-Friedrich: Der Entwurf einer Richtlinie zur Harmonisierung der Rechnungslegungsvorschriften für Versicherungsunternehmen, in: WPg, 32. Jg. (1979), S. 545-552.

LAASS, Wolfgang: Die Gliederung des Jahresabschlusses für EG-Versicherungsunternehmen nach dem VU-Sonderrichtlinien-Entwurf vom 20. Juni 1979, in: WPg, 34. Jg. (1981), S. 409-424.

LORCH, Manfred: Publizitätsorientierte Gestaltung der Rechnungslegungsvorschriften für Versicherungsunternehmen, Karlsruhe 1974.

OOS, Johannes: Zum Ausweis des passiven Rückversicherungsgeschäfts im Rechnungsabschluß der Schaden- und Unfallversicherungsunternehmen, in: WPg, 32. Jg. (1979), S. 604-613.

PERLET, Helmut: Rückstellungen für noch nicht abgewickelte Versicherungsfälle in Handels- und Steuerbilanz, Karlsruhe 1986.

RICHTER, Horst: Aussagewert der Spartenrechnung, in: WÜBA-Gazette - Jubiläumsausgabe zum 150jährigen Bestehen der Württembergischen und Badischen Versicherungs-Aktiengesellschaft, Heilbronn 1987, S. 12-14.

WELZEL; Hans Joachim: Grundsatzfragen zur Reform der öffentlichen Rechnungslegung von Versicherungsunternehmen, in: VW, 28 Jg. (1973), S. 367-372 und S. 422-431. 